\begin{tabular}{|c|c|}
\hline \multirow{3}{*}{ 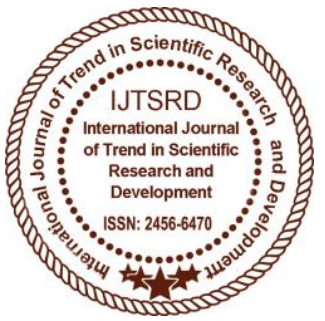 } & $\begin{array}{l}\text { International Journal of Trend in Scientific } \\
\text { Research and Development (IJTSRD) }\end{array}$ \\
\hline & International Open Access Journal \\
\hline & ISSN No: 2456 - 6470 | www.ijtsrd.com | Volume - 1 | Issue - 5 \\
\hline
\end{tabular}

\title{
Trends and Levels of Female Literacy in Belagavi District
}

\author{
Manjunatha N K \\ Assistant Professor and Research Scholar, \\ Department of Geography, Rani Channamma \\ University, Vidyasangama, PBNH-4, \\ Belagavi, Karnataka, India
}

\author{
S M Hurakadli \\ Professor and Chairman, Department of Geography, \\ Rani Channamma University, Vidyasangama, \\ PBNH-4, Belagavi, Karnataka, India
}

\section{ABSTRACT}

Women education plays a very important role in the overall growth of the country. It does not only help in the development of half of the human capital but also improves the standard of living. The progress of the nation or region is shown by the level of education and literacy of its population. Education, particularly among women has been considered as one of the major aspects for socio-economic development of the people of a region. Belagavi district is among the rapidly developing districts in Karnataka with respect to socio-economic and agricultural development. According to 2011 census, average literacy rate of Belagavi district $(73.48 \%)$ is lower than the average literacy rate of Karnataka state $(75.60 \%)$.(Office of the Registrar General and Census Commissioner, India, 2011) This can be attributed to greater regional disparities throughout Belagavi district in literacy. In this paper, we present Provisional Population Totals of census 2001 and 2011 and examine the extent of literacy disparities at the taluk level. Here, we found that literacy rate in the study area was $64.21 \%$ in 2001 which has increased to $73.48 \%$ in 2011 . We also found that the urban literacy $(85.56 \%)$ is significantly greater than the rural literacy $(69.28 \%)$ which is concurrent to the wider gender disparities from the rural to the urban population.

Keywords: Female Literacy; Disparity; Population; Frequency distribution

\section{INTRODUCTION}

Educate a man and he will leave his home to find work. Educate a woman and she will have fewer children, introduce better health practices to her family and village, run her household more efficiently, and most important, advocate for the education of her children.(Marstaller, 2000)The female education which influences on fertility and mortality rates and age at the time of marriage of women, in turn, helps control population number. As a matter of fact, literacy attainment is a part of larger societal changes and it needs to be placed in proper perspective, without which the regional distortions as well as gender discriminations will not disappear even as general literacy rises.(Raju, 1993)

Belagavi district, the second largest of Karnataka state was the part of Presidency of Bombay(Census of India 2011 Karnataka, 2011). It is situated at foothills of Western Ghats (Sahyadri hills) in the north-western part of the state. The Belagavi district is between 450to900 meters above mean sea level and the geographical area of Belagavi district is 13,379 Sq. $\mathrm{km}$. which is $6.99 \%$ of the total geographical area of the state. It extends about $160 \mathrm{~km}$ from north to south and $80-130 \mathrm{~km}$ from east to west and forms a large plane scattered with solitary peaks broken here and there by low range of hills. The Belagavi district is crossed from west to east by two great spurs, the Ghataprabha and the Malaprabha spurs. This region consists of long sandstone ridges with grass cover on steep slopes. The black soils predominates the Deccan trap terrain and the red soils are formed in the south western and south eastern part of the district in the Gneissic terrain (Raychaudhari, 1963). Belagavi district has a total of 1, 90,424 hectares; of land under forest cover and has the fifth place in forest area. 
International Journal of Trend in Scientific Research and Development (IJTSRD) ISSN: 2456-6470

Belagavi district is one of the socio-economically developed districts in Karnataka. Present study is focused on the trends and levels of female literacy in Belagavi District. The average literacy rate of Belagavi district $(73.48 \%)$ is lower than the average literacy rate of Karnataka state $(75.60 \%)$ according to 2011 census. As elsewhere in the country, in Belagavi district, the level of female literacy is not only lower than that of the males but also varied in spatial and social terms.

\section{OBJECTIVES}

The foremost purpose of this study is to examine the trends and levels of female literacy of Belagavi district during 2001 to 2011.

\section{STUDY AREA}

The study area of this paper is a part of Karnataka. The region under study extends from $15^{\circ}-23^{\prime}$ north to $16^{\circ}-58^{\prime}$ north latitudes and $74^{\circ}-05^{\prime}$ east to $75^{\circ}-28^{\prime}$ east longitudes(“Belgaum Dist Gazetteer 1987)The district is divided into 10 taluks for administrative purposes viz., Athani, Belgavi, Chikodi, Gokak, Hukeri, Khanapur, Parasgad (Saundatii), Ramdurg, Raybag and Sampgaon (Bailhongal). Khanapur is the biggest taluk with an area of $1749.3 \mathrm{Sq} . \mathrm{km}$ and Raybag is the smallest taluk with an area of $958.8 \mathrm{Sq}$. $\mathrm{km}$. Belagavi district is bordered by Maharashtra state in the North, Bagalkot district in the East, Dharwad and Uttar Kannada districts in the South, Goa and Maharastra state in the west. The area of the district is $13,415 \mathrm{Sq}$. km. According to 2011 census the total population of the district is $47,78,439$ with literacy rate $73.48 \%$.

\section{MAP 1- LOCATION MAP OF BELAGAVI DISTRICT IN INDIA}

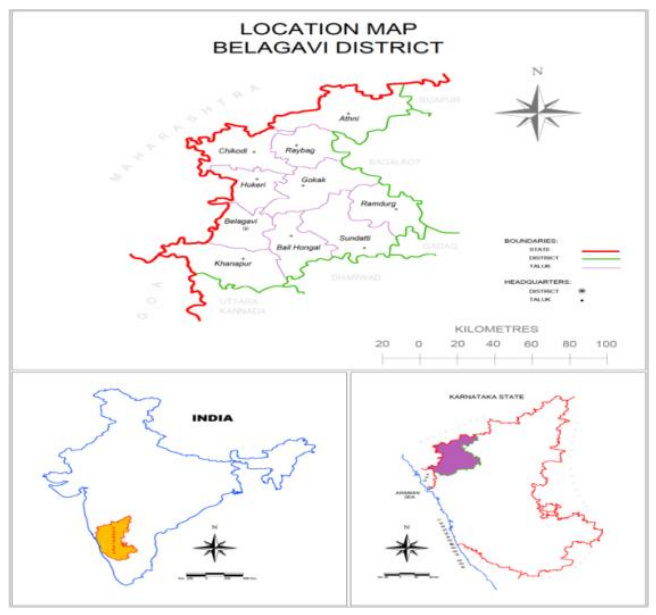

\section{DATABASE AND METHODOLOGY}

The present paper aims to study the trends and levels of female literacy in Belagavi district based on secondary data obtained from district census handbook of Belagavi district, statistical abstracts of Belagavi and Karnataka state and census of India 2011. Other various sources of secondary data have been utilized such as internet and books. Literacy rate has been computed for the population above 6 years. For the measurement of male female disparity in literacy, the Sopher's disparity index (1974) modified by Kundu and Rao (1983) has been employed (Hajare \& Ghurake, 2014).

\section{FORMULA}

$$
D M S=\log \frac{X 2}{X 1}+\log \frac{200-X 1}{200-X 2}+\cdots
$$

Where,

$\mathrm{X} 2$ is more than $\mathrm{X} 1 . \mathrm{X} 2=$ is considered Male. $\mathrm{X} 1=\mathrm{is}$ considered Female

\section{TRENDS IN LITERACY RATE (INDIA AND KARNATAKA)}

As per the provisional population totals of Census 2011 , literates in India constitute $74 \%$ of the total population aged seven and above and illiterates form $26 \%$. Literacy rate has gone up from $64.83 \%$ in 2001 to $74.04 \%$ in 2011 showing an increase of 9.21 percentage points. The literacy rate for males and females works out to $82.14 \%$ and $65.46 \%$, respectively. The increase in literacy rate in males and females during 2001-2011 is in the order of 6.88 and 11.79 percentage points and the literacy rate of Karnataka increased from $66.64 \%$ in 2001 to $75.36 \%$ in 2011. Among the females, the literacy percentage has increased from $56.87 \%$ in 2001 to $68.08 \%$ in 2011.The literacy rate of Karnataka is higher than the India's literacy rate.

\section{LITERACY RATE - TRENDS (Belagavi District)}

According to 2011 census, the average literacy in Belagavi district is $73.48 \%$ compared to $61.4 \%$ in 2001. The highest literacy rate is $83.68 \%$ in Belagavi taluk and lowest literacy rate is $66.36 \%$ in Ramdurg taluk, respectively. Leading part of female literacy is found in Belagavi taluk $77.54 \%$ followed by Khanapur taluk (66.39\%) and lowest literacy of 
International Journal of Trend in Scientific Research and Development (IJTSRD) ISSN: 2456-6470 female is found in Raibag taluk $54.94 \%$ in 2011 . The average literacy of female population in Belagavi district is $64.58 \%$ in 2011 , compared to $52.30 \%$ in 2001 and the female rural literacy of Belagavi district is $59.20 \%$ and urban female literacy is $79.95 \%$, respectively. There is a wide gap from average male to female literacy as well as rural $(69.28 \%)$ to urban literacy $(85.56 \%)$ in Belagavi district.

Table 1- Frequency distribution of districts by levels of female literacy over 2001 and 2011

\begin{tabular}{|c|c|c|}
\hline \multirow{2}{*}{ Class interval } & \multicolumn{2}{|r|}{ Female literacy rate } \\
\hline & 2001 & 2011 \\
\hline Up to 40 & 00 & 00 \\
\hline $40-55$ & $\begin{array}{l}08 \text { (Athani, Bailhongal, Gokak, } \\
\text { Hukkeri, Khanapur, Raibag, } \\
\text { Ramdurg, Savadatti) }\end{array}$ & 01 ( Ramdurg) \\
\hline $55-70$ & 02 (Belgavi, Chikkodi.) & $\begin{array}{l}08 \text { (Athani, Bailhongal, Chikkodi, Gokak, Hukkeri, } \\
\text { Khanapur, RaibagSavadatti) }\end{array}$ \\
\hline 70 onwards & & 1( Belagavi) \\
\hline
\end{tabular}

Data sources: Calculated by using data taken from the 2001 and 2011 Population Censuses.

\section{Figure 1- Frequency Distribution of Taluks By Levels Of Female Literacy Over 2001 and 2011 censuses}

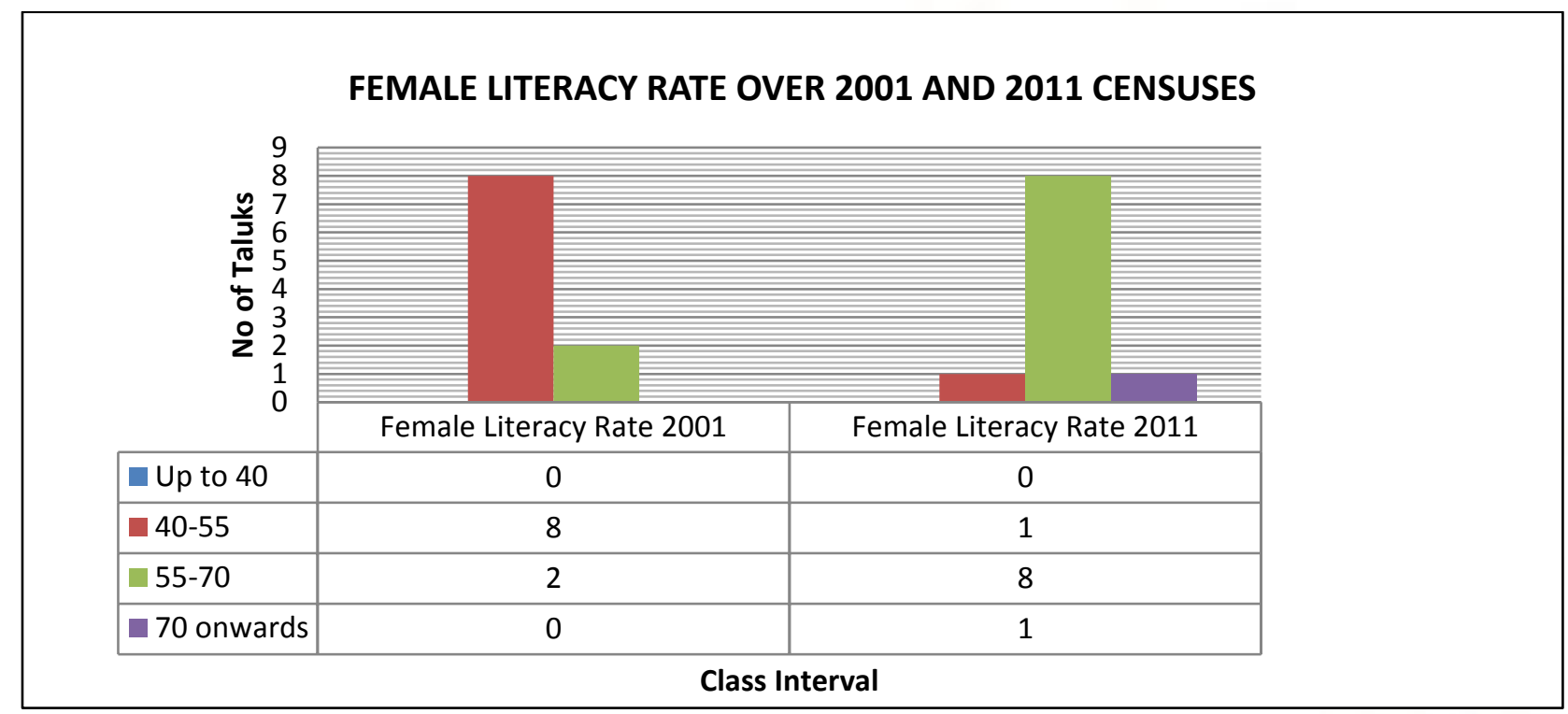

Data sources: Calculated by using data taken from the 2001 and 2011 Population Censuses.

Figure 1 presents the frequency distribution of taluks by levels of female literacy over 2001 and2011censuses. As per the Provisional totals of census of India, data are available for Belagavi districts in the country for 2001 and 2011.Table 1 shows the literacy rate among females to be below $40 \%$ is zero in any taluks of Belagavi districts in census year2001 and 2011.In the middle level literacy band (40 to 55\%), 8 taluks have reduced to 1 taluk (2001-2011). In addition, in the high level of literacy development band (55-70\%), there were 2 two taluks in the year 2001, which have increased to 8 taluks in 2011.In the very high literacy development band 
International Journal of Trend in Scientific Research and Development (IJTSRD) ISSN: 2456-6470

(70 onwards), there were zero taluks in the year 2001, which have increased to 1 taluk in 2011. Among all the talukas of Belagavi district, Belagavi taluk has highest female literacy rate of $77.54 \%$ in 2011.

Table 2-Literate Population and Literacy Rate-2001 and 2011

\begin{tabular}{|c|c|c|c|c|c|c|c|c|c|c|c|c|}
\hline \multirow{2}{*}{$\begin{array}{l}\text { Name of } \\
\text { Taluks }\end{array}$} & \multicolumn{3}{|c|}{ Literate Population-2001 } & \multicolumn{3}{|c|}{ Literate Population-2011 } & \multicolumn{3}{|c|}{ Literacy Rate \% 2001} & \multicolumn{3}{|c|}{ Literacy Rate \% 2011} \\
\hline & Total & Male & Female & Total & Male & Female & Total & Male & Female & Total & Male & Female \\
\hline Athani & 239507 & 1381748 & 92353 & 320240 & 182933 & 137307 & 61.4 & 72.54 & 49 & 70.42 & 79.06 & 61.47 \\
\hline Bailhongal & 191258 & 115203 & 76055 & 243796 & 137777 & 106019 & 63.37 & 75.44 & 50.99 & 72.9 & 81.8 & 63.87 \\
\hline Belgavi & 55244 & 312816 & 239625 & 710306 & 386047 & 324259 & 78.31 & 86.46 & 69.71 & 83.68 & 89.63 & 77.54 \\
\hline Chikkodi & 335278 & 200145 & 135133 & 421750 & 121711 & 183425 & 68.83 & 81.56 & 56.63 & 76.06 & 84.89 & 67 \\
\hline Gokak & 245330 & 152533 & 92797 & 350329 & 201803 & 148526 & 55.9 & 68.7 & 42.84 & 67.54 & 77.75 & 57.31 \\
\hline Hukkeri & 189455 & 115250 & 74205 & 248254 & 140675 & 107579 & 62.09 & 74.69 & 49.15 & 71.64 & 81.21 & 62.08 \\
\hline Khanapur & 137260 & 81290 & 55970 & 172075 & 97471 & 74604 & 65.99 & 78.06 & 53.83 & 75.65 & 84.69 & 66.39 \\
\hline Raibag & 161035 & 98835 & 62200 & 231045 & 132591 & 98454 & 55.68 & 66.62 & 44.14 & 67.02 & 75.53 & 58.2 \\
\hline Ramdurg & 104939 & 66941 & 37998 & 146022 & 86215 & 59807 & 55.05 & 69.42 & 40.36 & 66.36 & 77.53 & 54.94 \\
\hline Savadatti & 148776 & 94036 & 54740 & 208215 & 238325 & 86504 & 56.68 & 71.65 & 42.21 & 68.64 & 79.33 & 57.69 \\
\hline $\begin{array}{c}\text { Belagavi } \\
\text { district } \\
\text { total }\end{array}$ & $\begin{array}{c}230525 \\
9\end{array}$ & 144699 & 94808 & $\begin{array}{c}305203 \\
2\end{array}$ & $\begin{array}{c}172554 \\
8\end{array}$ & 1326484 & 64.20 & 75.70 & $\mathbf{5 2 . 3 0}$ & 73.48 & 82.2 & 64.58 \\
\hline
\end{tabular}

Data sources: Calculated by using data taken from the 2001 and 2011 Population Censuses.

\section{DISPARITY IN MALE /FEMALE LITERACY}

Belgavi District literacy rate in 2011 is $73.48 \%$ where as in 2001 it is $61.4 \%$. The male-female disparity was 0.235 in 2001, while 0.165 in 2011. Table 2 shows that the literacy rate in the study area varied from a minimum of $66.36 \%$ in Ramdurg taluk to a maximum of $83.68 \%$ in Belagavi taluk of Belagavi district. In the study area the male literacy was $82.2 \%$ and for female was $64.58 \%$ in 2011 . It shows a wide gap of $17.62 \%$ literacy from male to female. Table 3 observed that minimum male literacy was in Raibag taluk $75.53 \%$ and maximum in Belagavi taluk $89.63 \%$ in Belagavi district. There was observed that the minimum female literacy was $54.94 \%$ in Ramdurg taluk to a maximum of $77.54 \%$ in Belagavi taluk. It shows that there are wide disparities from the male-female literacy rates.

As compared to 2001 disparity of literacy decreased by $0.07 \%$ in 2011, because of increased literacy rate. Highest disparity of male and female is observed in Ramdurg taluk (0.223) followed by Savadatti taluk (0.209), because of wide gap from male to female literacy. Lower disparity of literacy in male and female observed in Belagavi taluk (0.108), because, Belagavi taluk of Belagavi District experiences high literacy rate of both in male and female.

Figure 2- Disparity of male and female literacy in Belagavi district over 2001 and 2011

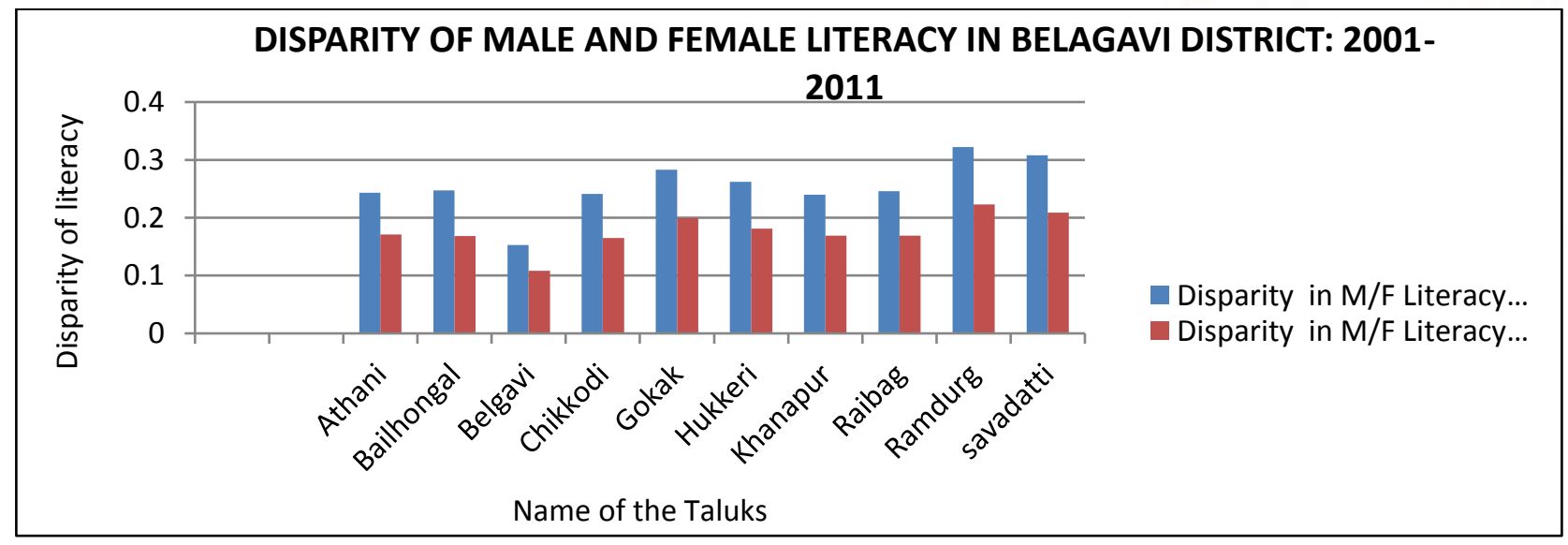


International Journal of Trend in Scientific Research and Development (IJTSRD) ISSN: 2456-6470

\section{COMPOSITE INDEX}

Composite index of disparity is calculated by using the following formula:

Composite Index of Disparity $=\frac{\text { (Disparity of literacy 2001 }+ \text { Disparity of literacy 2011) }}{2}$.

\section{A. High Composite Index (Above 0.240)}

In Belagavi district an average composite index is observed 0.200. There is a wide gap from the higher to the lower composite index in district. In Ramdurg taluk composite index is 0.272 which is highest in district, because of disparity of literacy in this taluk is high i.e. 0.223. In Savadatti taluk composite index is 0.258 and in Gokak taluk (0.241), respectively. Higher composite index includes Ramdurg taluk, Savadatti taluk and Gokak taluk in Belagavi districts. (Figure 3)

\section{B. Moderate Composite Index (from 0.200 to 0.240):}

Moderate composite index ranges from 0.200 to 0.240. In this composite index includes Athani (0.207) Bailhongal(0.207) Chikkodi(0.203) Hukkeri(0.221) Khanapur(0.204) Raibag(0.207) in this six taluks have medium composite index observed, because the same taluks having moderate disparity of literacy (Figure 3)

\section{Low Composite Index (Below 0.200)}

Low composite index is below 0.200 is found only in one taluk of Belgavi district, i.e., Belagavi taluk (0.130) because disparity of literacy is lower in this taluk (0.108), respectively (Figure 3 ).

Table 3-Disparity of literacy trend of Belagavi district, 2001-2011 and Composite Index (in percentages)

\begin{tabular}{|c|c|c|c|c|c|c|c|}
\hline \multirow{2}{*}{$\begin{array}{c}\text { Name of } \\
\text { Taluks }\end{array}$} & \multicolumn{2}{|c|}{ Literacy-2001 } & \multirow{2}{*}{$\begin{array}{c}\text { Disparity } \\
\text { Of } \\
\text { Literacy }\end{array}$} & \multicolumn{2}{|c|}{ Literacy-2011 } & \multirow{2}{*}{$\begin{array}{c}\text { Disparity } \\
\text { in } \mathrm{M} / \mathrm{F} \\
\text { Literacy }\end{array}$} & \multirow{2}{*}{$\begin{array}{l}\text { Composite } \\
\text { index }\end{array}$} \\
\hline & Male & Female & & Male & Female & & \\
\hline Athani & 72.54 & 49.00 & 0.243 & 79.06 & 61.47 & 0.171 & 0.207 \\
\hline Bailhongal & 75.44 & 50.99 & 0.247 & 81.8 & 63.87 & 0.168 & 0.207 \\
\hline Belagavi & 86.46 & 69.71 & 0.153 & 89.63 & 77.54 & 0.108 & 0.130 \\
\hline Chikkodi & 81.56 & 56.63 & 0.241 & 84.89 & 67.00 & 0.165 & 0.203 \\
\hline Gokak & 68.70 & 42.84 & 0.283 & 77.75 & 57.31 & 0.199 & 0.241 \\
\hline Hukkeri & 74.69 & 49.15 & 0.262 & 81.21 & 62.08 & 0.181 & 0.221 \\
\hline Khanapur & 78.06 & 53.83 & 0.240 & 84.69 & 66.39 & 0.169 & 0.204 \\
\hline Raibag & 66.62 & 44.14 & 0.246 & 75.53 & 58.2 & 0.169 & 0.207 \\
\hline Ramdurg & 69.42 & 40.36 & 0.322 & 77.53 & 54.94 & 0.223 & 0.272 \\
\hline savadatti & 70.47 & 42.21 & 0.308 & 79.33 & 57.69 & 0.209 & 0.258 \\
\hline Belagavi district total & 75.70 & 52.30 & 0.235 & 82.2 & 64.58 & 0.165 & 0.200 \\
\hline
\end{tabular}

Data sources: Calculated by using data taken from the 2001 and 2011 Population Censuses 
Figure 3- Taluk wise composite index of Belagavi district

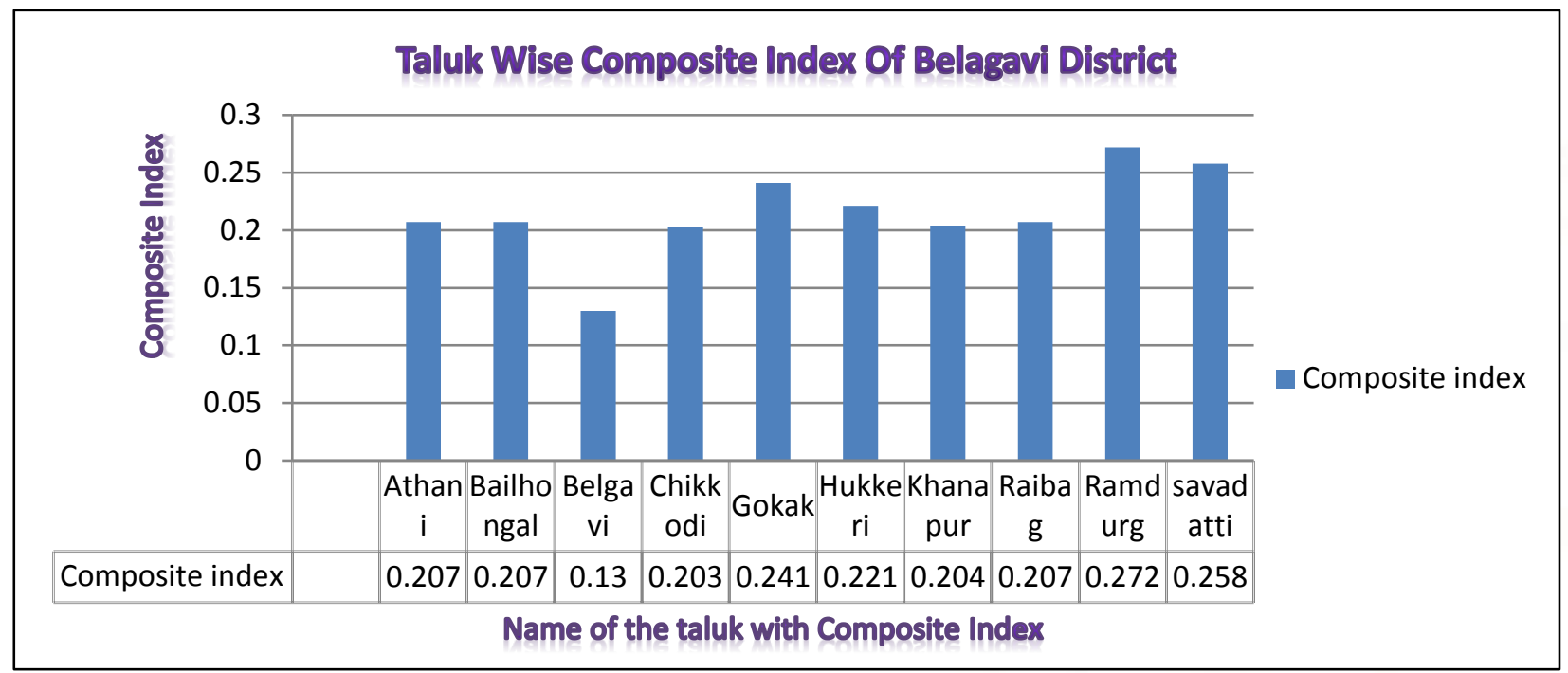

Table 4-Literacy rates by sex and their decadal differences between 2001 and 2011, Belagavi district and Taluks.

\begin{tabular}{|c|c|c|c|c|c|c|c|c|}
\hline \multirow{2}{*}{$\begin{array}{l}\text { Name of } \\
\text { Taluks }\end{array}$} & \multicolumn{2}{|c|}{2001} & \multirow{2}{*}{$\begin{array}{l}\text { Gender } \\
\text { Gap in } \\
\text { literacy } \\
\text { rate }\end{array}$} & \multicolumn{2}{|c|}{2011} & \multirow{2}{*}{$\begin{array}{c}\text { Gender } \\
\text { Gap in } \\
\text { literacy } \\
\text { rate }\end{array}$} & \multicolumn{2}{|c|}{$\begin{array}{l}\text { Decadal } \\
\text { difference }\end{array}$} \\
\hline & Male & Female & & Male & Female & & Male & Female \\
\hline Athani & 72.54 & 49.00 & 23.54 & 79.06 & 61.47 & 17.59 & 6.52 & 12.47 \\
\hline Bailhongal & 75.44 & 50.99 & 24.45 & 81.8 & 63.87 & 17.93 & 6.36 & 12.88 \\
\hline Belagavi & 86.46 & 69.71 & 16.75 & 89.63 & 77.54 & 12.09 & 3.17 & 7.83 \\
\hline Chikkodi & 81.56 & 56.63 & 24.93 & 84.89 & 67.00 & 17.89 & 3.33 & 10.37 \\
\hline Gokak & 68.7 & 42.84 & 25.86 & 77.75 & 57.31 & 20.44 & 9.05 & 14.47 \\
\hline Hukkeri & 74.69 & 49.15 & 25.54 & 81.21 & 62.08 & 19.13 & 6.52 & 12.93 \\
\hline Khanapur & 78.06 & 53.83 & 24.23 & 84.69 & 66.39 & 18.3 & 6.63 & 12.56 \\
\hline Raibag & 66.62 & 44.14 & 22.48 & 75.53 & 58.20 & 17.33 & 8.91 & 14.06 \\
\hline Ramdurg & 69.42 & 40.36 & 29.06 & 77.53 & 54.94 & 22.59 & 8.11 & 14.58 \\
\hline savadatti & 70.47 & 42.21 & 28.26 & 79.33 & 57.69 & 21.64 & 8.86 & 15.48 \\
\hline $\begin{array}{l}\text { Belagavi } \\
\text { district total }\end{array}$ & 75.70 & 52.30 & 23.4 & 82.2 & 64.58 & 17.62 & 6.50 & 12.28 \\
\hline
\end{tabular}

Data sources: Calculated by using data taken from the 2001 and 2011 Population Censuses

\section{DECADAL VARIATION IN FEMALE LITERACY}

The district level female literacy rate has increased from $52.30 \%$ in 2001 to $64.58 \%$ in 2011 , an increase of $12.28 \%$ during the decade. If we look at the performance of individual taluks in terms of
Increasing female literacy rates, the results are interesting. Belagavi is the slowest as its female literacy rate between 2001 and 2011 increases by 7.83\% followed by Chikkodi (10.37\%) and Athani $(12.47 \%)$, whereas high growth in female literacy rate 
International Journal of Trend in Scientific Research and Development (IJTSRD) ISSN: 2456-6470

is observed in savadatti (15.48\%), Ramdurg (14.58\%), Gokak (14.47\%) and Raibag (14.06\%). These are known as highly illiterate taluks achieved significant improvements in literacy among females. Looking at the data in table 4 and trend analysis, we are concluding that the taluks where the overall literacy rate is low, they continue to have large gap in malefemale literacy rates even after considerable development in female literacy.

\section{A. Male-Female Differential in Literacy rate in the Belagavi District}

The Gender gap in literacy rate in the Belagavi District has declined from $23.4 \%$ in 2001 to $17.62 \%$ in 2011 due to faster increase in literacy among females than male. Subsequently, thegender gap in literacy declined in all the taluks of Belagavidistricts during this period.

\section{FINDINGS AND CONCLUSION}

Among 10 taluks of Belagavi district the Ramdurg taluk is having medium level female literacy band of low level of economic development of (40-55\%) and desires special attention for improvement in literacy among female. Among 8 taluks of district; Athani, Bailhongal, Chikkodi, Gokak, Hukkeri, Khanapur, Raibag, Savadatti fall under high level of literacy development band (55-70\%), even though, The
National literacy mission and the Sarvasiksha abhiyan both could not achieve target of $75 \%$ literacy among females from census year 2001 to census year 2011.The cumulative results shows that from 2001 to 2011 there is marginal increase in female literacy rate in various taluks of Belagavi district which confirms that Government programmes show results but need to be applied efficiently for superior results.

\section{REFERENCES}

1) Belgaum Dist Gazetteer 1987 Chp 01.pdf. (n.d.).

2) Census of India 2011 KARNATAKA. (2011). District census handbook Belgaum.

3) Hajare, R. V, \& Ghurake, B. B. (2014). Regional disparity in literacy of Kolhapur district, (March), 269-278.

4) Marstaller, B. A. (2000). First Things First: Female Literacy as the Key to Women's Advancement, (1992), 10-13.

5) Office of the Registrar General and Census Commissioner, India. (2011). Census 2011. Retrieved from http://www.census2011.co.in/literacy.php

6) Raju, S. (1993). Nuna, S. C. (ed) Regional disparities in Educational Development, South Asian Publishers Pvt Ltd, New Delhi.

7) Raychaudhari, S. P. (1963). Land resources in india,( vol 1)Indian Soils-Planning Commission,New Delhi. 